\title{
Identification of the F129L mutation among isolates of Pyrenophora teres Drechsler from central-western Poland
}

\section{Identyfikacja mutacji F129L wśród izolatów Pyrenophora teres Drechsler pochodzących ze środkowo-zachodniej Polski}

\author{
Patrycja Marciniak $^{1} *$, Tomasz Kosiada ${ }^{1}$, Łukasz Wolko ${ }^{2}$
}

\begin{abstract}
Summary
Barley (Hordeum vulgare L.) is one of the major cereal species cultivated worldwide. World production of barley is over 140 million tons. Fungal diseases usually cause significant yield losses. A major risk for crops is net blotch of barley disease caused by Pyrenophora teres. Pathogen rapidly develops resistance to fungicides and it is usually a result of a point mutation. In this study the isolates from central and western part of Poland were tested and the efficacy of Qol against $P$. teres was investigated. Based on the results of the in vitro tests of sensitivity of some isolates the analysis of a fragment containing the F129L mutation in the cytochrome $b$ gene was performed. The average growth inhibition degree was $46.5 \%$. Although partial insensitivity to fungicides were observed for some isolates, the mutations have not be detected.
\end{abstract}

Key words: Pyrenophora teres; net blotch of barley; Qol resistance

\section{Streszczenie}

Jęczmień (Hordeum vulgare L.) jest jednym z najczęściej uprawianych zbóż na całym świecie. Światowa produkcja jęczmienia wynosi ponad 140 milionów ton. Choroby, których sprawcami są grzyby przyczyniają się do znaczącego obniżenia plonów. Duże zagrożenie dla upraw jęczmienia stanowi Pyrenophora teres, sprawca plamistości siatkowej jęczmienia. Grzyb dość szybko nabywa odporność na niektóre ze stosowanych środków ochrony roślin. Odporność jest zazwyczaj skutkiem mutacji punktowej. W niniejszej pracy badano izolaty pochodzące z rejonów środkowo-zachodniej Polski. W oparciu o wyniki testu wrażliwości patogena na fungicydy strobilurynowe wykonano analizę fragmentu genu cytochromu $b$, zawierającego mutację w 129 pozycji sekwencji aminokwasowej białka. Średnia wartość stopnia hamowania wzrostu wyniosła 46,5\%. Mimo zaobserwowania częściowej niewrażliwości na Qol prawie u połowy badanych izolatów, nie zidentyfikowano szczepów grzyba posiadających substytucję F129L.

Słowa kluczowe: Pyrenophora teres; plamistość siatkowa jęczmienia; odporność na strobiluryny

\footnotetext{
Uniwersytet Przyrodniczy w Poznaniu

${ }^{1}$ Katedra Fitopatologii i Nasiennictwa

Dąbrowskiego 159, 60-594 Poznań

${ }^{2}$ Katedra Biochemii i Biotechnologii

Dojazd 11, 60-632 Poznań

*corresponding author: patrycja.marciniak@up.poznan.pl
} 


\section{Wstęp / Introduction}

Jęczmień zwyczajny (Hordeum vulgare L.) należy do rzędu Poales i rodzaju Hordeum, w którym jest jedynym gatunkiem uprawnym. Powierzchnia upraw jęczmienia w Polsce w 2015 roku wyniosła 839 tys. ha, a wielkość zbiorów to ponad 2,9 mln ton (GUS 2016). W skali światowej jęczmień pod względem zasiewów zajmuje czwarte miejsce wśród zbóż uprawnych, zaraz za pszenicą, ryżem i kukurydzą. Jęczmień wykorzystywany jest głównie na paszę (70-80\%), a także do produkcji pieczywa, kaszy oraz słodu jęczmiennego w przemyśle browarniczym (Gąsiorowski 1997).

Do najważniejszych patogenów jęczmienia należy Pyrenophora teres powodujący plamistość siatkową jęczmienia, grzyb zaliczany jest do typu Ascomycota. Wyróżnia się dwie formy patogena: $P$. teres f. teres i $P$. teres f. maculata. Każda $\mathrm{z}$ tych form odpowiada za inny rodzaj objawów chorobowych (Kryczyński i Weber 2011).

Plamistość siatkowa jęczmienia jest główną przyczyną obniżenia plonu jęczmienia, straty mogą sięgać nawet 40\%. Źródłem choroby są zakażone ziarniaki oraz resztki pożniwne, na których występują zarodniki workowe powstające $\mathrm{w}$ pseudotecjach. Wystąpieniu choroby sprzyja temperatura $\left(5-18^{\circ} \mathrm{C}\right)$ oraz wysoka wilgotność powietrza (Hani i wsp. 1998; Kryczyński i Weber 2011).

Do zwalczania plamistości siatkowej jęczmienia wykorzystywane są m.in. fungicydy. Substancje te zaburzają przebieg kluczowych procesów życiowych patogena. Głównie stosowane są środki należące do grupy fungicydów QoI (Quinone 'outer' inhibitor) oraz fungicydy triazolowe (Zalecenia 2016/2017). Do najczęściej używanych substancji czynnych wśród inhibitorów Qo zaliczamy strobiluryny, np. azoksystrobinę. Związki $\mathrm{z}$ tej grupy zaburzają procesy energetyczne związane z produkcją ATP w mitochondriach. Powodują one zablokowanie transportu elektronów pomiędzy cytochromem b i c1 (Anke 1995; Broniarek-Niemiec 2016).

Nadmierne i niewłaściwe stosowanie fungicydów strobilurynowych przyczyniło się do wykształcenia przez niektóre grzyby odporności. Proces ten jest naturalnym zjawiskiem ewolucyjnym wynikającym z presji selekcyjnej. Zjawisko odporności przyczynia się do ogromnych strat finansowych zarówno w rolnictwie, jak i w przemyśle produkcji środków ochrony roślin (Deising i wsp. 2008; Pieczul 2015).

Odporność na fungicydy strobilurynowe często warunkują mutacje punktowe w genie kodującym cytochrom $b$ - podjednostkę kompleksu mitochondrialnego cytochromu bc1. Mutacje te mają charakter substytucji, czyli zastąpienia jednego nukleotydu w konkretnej pozycji genu przez inny. Za omawianą odporność odpowiada zazwyczaj zmiana w pozycji aminokwasowej 143 lub 129 cytochromu $b$. Pierwsza substytucja (G143A) powoduje zmianę kodonu GGT na GCT $(\mathrm{G}>\mathrm{C})$, w efekcie glicyna zastąpiona zostaje alaniną. Druga mutacja (F129L), odpowiedzialna za częściową odporność na QoI u $P$. teres polega na zastąpieniu fenyloalaniny przez leucynę w 129 pozycji aminokwasowej cytochromu $b$. Zmiana ta wynika z jednego z trzech polimorfizmów mutacji zmieniających kodon fenyloalaniny (TTC) w kodony leucyny
(TTA, TTG lub CTC) (Semar i wsp. 2007). U P. teres i $P$. tritici-repentis zaobserwowano również inną, rzadziej występującą mutację - G137R, polegającą na zamianie glicyny argininą. Mutacja ta nie ma znaczącego wpływu na poziom odporności grzybów na fungicydy strobilurynowe (Marzani 2011).

Celem badań była identyfikacja mutacji F129L, warunkującej częściową niewrażliwość na fungicydy QoI wśród izolatów P. teres.

\section{Materiały i metody / Materials and methods}

Izolaty $P$. teres wykorzystane $\mathrm{w}$ badaniach uzyskano $\mathrm{z}$ liści jęczmienia $\mathrm{z}$ wyraźnymi objawami plamistości siatkowej jęczmienia. Pochodziły one $\mathrm{z}$ pięciu lokalizacji znajdujących się na terenie środkowo-zachodniej Polski: Poznania, Kościelca (gmina Pakość), Bukowca (gmina Nowy Tomyśl), Wiatrowa (gmina Wągrowiec) oraz Choryni (gmina Kościan). Materiał pobierano z pól doświadczalnych i uprawnych w 2015 roku, w miesiącach od marca do maja.

Do izolacji DNA (deoxyribonucleic acid) wykorzystano 2-tygodniową grzybnię $P$. teres hodowaną na płynnej pożywce glukozowej z dodatkiem wyciągu drożdżowego (5 g glukozy i 1 g ekstraktu drożdżowego na $1000 \mathrm{ml}$ wody destylowanej). Izolację wykonano według zmodyfikowanej procedury Doyle'a (Doyle i Doyle 1987; Aamir i wsp. 2015).

Tradycyjną identyfikację $P$. teres opartą na obserwacji makro- i mikroskopowej potwierdzono przy użyciu techniki PCR (polymerase chain reaction). W badaniu wykorzystano dwa zestawy specyficznych gatunkowo starterów (SCAR): DTT471h i DTM494d, które dodatkowo pozwalały na rozróżnienie form: $P$. teres $\mathrm{f}$. teres (91 pz) i $P$. teres f. maculata (161 pz) (Leisova i wsp. 2005; Baturo 2009). W tym celu przeprowadzono dwie niezależne reakcje. Mieszaniny reakcyjne zawierały po $5 \mu \mathrm{l} 2 \mathrm{x}$ PCR MIXu (A\&A Biotechnology, Polska), $50 \mathrm{ng}$ matrycy DNA, 0,2 $\mu$ l startera forward i reverse $(0,2 \mu \mathrm{M})$ oraz sterylną wodę, dodaną do łącznej objętości $10 \mu \mathrm{l}$. PCR prowadzono $\mathrm{w}$ następujących warunkach: wstępna denaturacja: $95^{\circ} \mathrm{C}-5$ min.; dla kolejnych 40 cykli denaturację prowadzano przez $30 \mathrm{~s} \mathrm{w} 95^{\circ} \mathrm{C}$; hybrydyzacja starterów: $30 \mathrm{~s} \mathrm{w} 62^{\circ} \mathrm{C}$ dla DTT471h, a w $55^{\circ} \mathrm{C}$ dla DTM494d, elongację w $72^{\circ} \mathrm{C}$ przez $40 \mathrm{~s}$, ostatni etap elongacji trwał $5 \mathrm{~min} .\left(72^{\circ} \mathrm{C}\right.$ ) (Leisova i wsp. 2005; Baturo 2009). W pracy przeanalizowano 40 izolatów.

Oceny wrażliwości izolatów $P$. teres na fungicydy strobilurynowe oraz identyfikacji potencjalnej odporności dokonano za pomocą testu polegającego na oznaczeniu stopnia zahamowania wzrostu w obecności fungicydu strobilurynowego. Na podstawie pomiaru wzrostu kolonii obliczono stopień hamowania wzrostu grzybni (w \%) wobec prób kontrolnych, rosnących bez dodatku fungicydu. W doświadczeniu użyto azoksystrobinę (Amistar 250 SC, Syngenta). Stężenie końcowe substancji czynnej w podłożu PDA (Potato Dextrose Agar, A\&A Biotechnology, Polska) wynosiło $20 \mathrm{ppm}$. Czterdzieści losowo wybranych 2-tygodniowych izolatów $P$. teres przepasażowano na 
przygotowane podłoże. Każdy izolat hodowano w trzech powtórzeniach. Kontrole w badaniu stanowiły kolonie rosnące na pożywce PDA bez fungicydu. Trzeciego i siódmego dnia hodowli dokonano pomiaru średnicy wyrosłych kolonii, wyliczono średni dobowy wzrost grzybni i obliczono stopień hamowania wzrostu izolatów przez azoksystrobinę. Analizę danych przeprowadzono w programie STATISTICA v. 12.0, wykorzystując w tym celu jednoczynnikową analizę wariancji (ANOVA) i test Newmana-Keulsa na poziomie istotności $\mathrm{p}=0,05$.

Do procedury PCR mającej na celu amplifikację fragmentu DNA zawierającego miejsce potencjalnej zmiany F129L wybrano 9 izolatów charakteryzujących się najmniejszą wrażliwością na działanie azoksystrobiny (stopień hamowania wzrostu poniżej 50\%). Startery CytbC1(F) i CytbC2(R) wykorzystane w reakcji pozwoliły na powielenie fragmentu genu cytochromu $b$ o wielkości 351 pz (Semar i wsp. 2007). Stosowano następujące warunki reakcji PCR: denaturacja wstępna $3 \mathrm{~min}$. w $95^{\circ} \mathrm{C}$, 36 cykli: denaturacja $\mathrm{w} 95^{\circ} \mathrm{C}-30 \mathrm{~s}$, annealing $\mathrm{w} 60^{\circ} \mathrm{C}$ - $30 \mathrm{~s}$, elongacja $\mathrm{w} 72^{\circ} \mathrm{C}-1 \mathrm{~min}$., końcowa elongacja 15 min. w $72^{\circ} \mathrm{C}$. Do mieszaniny reakcyjnej o objętości $100 \mu$ l używano: 2x PCR MIXu $(50 \mu \mathrm{l})$, wody sterylnej (38 $\mu \mathrm{l})$, każdego startera w ilości $0,2 \mu \mathrm{M}$ i 500 ng matrycy
DNA. Produkty PCR obserwowano w 1,5\% żelu agarozowym.

Otrzymany produkt PCR oczyszczono przy użyciu zestawu Clean-up (A\&A Biotechnology, Polska) zgodnie z protokołem producenta i przekazano do sekwencjonowania $(30 \mu \mathrm{l})$. Analizę wykonano w Macrogen Europe (Holandia). Uzyskane wyniki poddano analizie w programie ChromasPro oraz porównano za pomocą programu BLAST $\mathrm{z}$ sekwencją genu cytochromu $b$ P. teres (DQ919067.1) dostępną w bazie GenBank.

\section{Wyniki i dyskusja / Results and discussion}

Do identyfikacji izolatów wykorzystano technikę PCR. W efekcie rozdziału elektroforetycznego uzyskano produkty o długości 91 par zasad - potwierdzające identyfikację patogena jako $P$. teres oraz identyfikujące formę patogenów jako teres.

Wśród 40 izolatów średnia wartość stopnia hamowania wzrostu wyniosła 46,47\%. Prawie połowę izolatów (19) zakwalifikowano jako potencjalnie niewrażliwe na działanie fungicydów QoI, ze względu na mniejszy niż 50\% stopień hamowania wzrostu. Otrzymane wartości „stopnia

Tabela 1. Stopień hamowania wzrostu izolatów w obecności fungicydu strobilurynowego wraz z grupami jednorodnymi (test Newmana-Keulsa)

Table 1. Growth inhibition degree of Pyrenophora teres isolates in the presence of strobilurin fungicide and homogeneous groups (Newman-Keuls test)

\begin{tabular}{|c|c|c|c|}
\hline $\begin{array}{l}\text { Nr izolatu } \\
\text { Isolate No. }\end{array}$ & $\begin{array}{c}\text { Stopień zahamowania wzrostu } \\
\text { Growth inhibition degree } \\
{[\%]}\end{array}$ & $\begin{array}{l}\text { Nr izolatu } \\
\text { Isolate No. }\end{array}$ & $\begin{array}{c}\text { Stopień zahamowania wzrostu } \\
\text { Growth inhibition degree } \\
{[\%]}\end{array}$ \\
\hline 24 & 23,33 hijk & 97 & 34,57 fghij \\
\hline $33 / 1$ & 48,75 defghi & 98 & 60,19 bcde \\
\hline $33 / 2$ & 54,59 defghi & 99 & $7,09 \mathrm{jk}$ \\
\hline 34 & 64,69 abcde & 103 & 59,75 bcdefgh \\
\hline 40 & 82,60 abcd & 104 & 36,87 efghij \\
\hline 43 & 48,07 defghi & 107 & 52,78 defghi \\
\hline 46 & 55,61 defghi & 108 & $0,13 \mathrm{k}$ \\
\hline $48 / 1$ & 58,52 cdefgh & 109 & $93,33 \mathrm{ab}$ \\
\hline $48 / 2$ & 50,98 defghi & 114 & 79,53 abcd \\
\hline $48 / 3$ & 50,80 defghi & 116 & 39,47 efghij \\
\hline 49 & $19,44 \mathrm{ijk}$ & 120 & 46,99 defghi \\
\hline 59 & 34,62 fghij & 125 & 36,90 efghij \\
\hline 60 & 24,24 hijk & 127 & 48,07 defghi \\
\hline 61 & 94,29 a & 140 & 71,98 abcde \\
\hline 63 & 7,99 jk & 145 & $-77,30 \mathrm{~m}$ \\
\hline 65 & 76,85 abcd & 164 & 23,75 hijk \\
\hline 67 & 69,97 abcde & 166 & 47,22 defghi \\
\hline 73 & $83,33 \mathrm{abc}$ & 167 & 39,79 efghij \\
\hline $95 / 1$ & 28,30 ghijk & 171 & 60,94 bcde \\
\hline $95 / 2$ & 52,38 defghi & 181 & 67,43 abcde \\
\hline
\end{tabular}

Wartości oznaczone tymi samymi literami nie różnią się statystycznie w sposób istotny

Values marked by the same letters are not significantly different 
hamowania wzrostu” poddano obróbce statystycznej. Jednoczynnikowa analiza wariancji ANOVA potwierdziła różnice między izolatami. $\mathrm{Z}$ kolei za pomocą testu Newmana-Keulsa wyznaczono 12 grup jednorodnych o podobnych wartościach stopnia hamowania wzrostu (tab. 1).

W pracy Marzani (2011) opisano wpływ różnych stężeń fungicydów, w tym azoksystrobiny na wzrost $P$. teres typu dzikiego oraz izolatów z mutacją F129L. Wartość stopnia hamowania wzrostu izolatów przez azoksystrobinę była niższa niż dla izolatów poddanych działaniu innych fungicydów z grupy QoI. Mimo to nawet w przypadku izolatów ze zmianą F129L, azoksystrobina charakteryzowała się znaczną skutecznością (procent hamowania wzrostu utrzymywał się na poziomie 60-80\%). Oznacza to, że obecność mutacji F129L przekłada się na średni poziom odporności grzybów na fungicydy strobilurynowe (Marzani 2011).

Według obserwacji Sierotzkiego i wsp. (2007), autorów badań nad strukturą genu cytochromu b, mutacja F129L jest dość często spotykaną przyczyną niewrażliwości na fungicydy strobilurynowe wśród populacji $P$. teres na terenie Anglii, Szkocji i Francji. Po raz pierwszy odporność na QoI u P. teres zaobserwowano we Francji w 2003 roku (Sierotzki i wsp. 2007). Z czasem odporność wynikającą ze zmiany F129L obserwowano również w Wielkiej Brytanii, Niemczech, Belgii, Szwajcarii i Irlandii (Sierotzki i wsp. 2007). Dlatego w niniejszej pracy wykonano PCR z użyciem zestawu starterów odpowiadających za amplifikację fragmentu genu cytochromu $b$ o długości 351 pz. Fragment obejmował miejsce występowania mutacji F129L (GenBank NCBI, DQ919067).

Do analizy fragmentu sekwencji cyt $b$ wybrano 5 izolatów. Uzyskane sekwencje porównano z sekwencją genu cytochromu $b$ P. teres (nr akcesu: DQ919067) za pomocą programu BLAST. Nie zidentyfikowano mutacji F129L u badanych izolatów. W związku z tym wyklucza się, że przyczyną częściowej niewrażliwości izolatów $P$. teres badanych w pracy jest mutacja F129L. Podłożem zmniejszonej wrażliwości jest inny mechanizm.

Podobna sytuacja miała miejsce $\mathrm{w}$ badaniach Marzani (2011). Na 23 izolaty P. teres, które wykazywały niewraż- liwość na fungicydy strobilurynowe mutacja F129L pojawiła się w 10 przypadkach. W przypadku pozostałych prób zakładano obecność innych mutacji punktowych w obrębie części genu cyt $b$, która nie podlegała analizie (Marzani 2011). Z pewnością można odrzucić obecność mutacji G143A, która odpowiada za wysoki poziom odporności na fungicydy strobilurynowe m.in. u $P$. tritici-repentis, czy Cercospora beticola. Do mutacji nie dochodzi u organizmów, u których za trójką nukleotydów w pozycji 143 występuje intron. Wynika to z niewłaściwego przebiegu splicingu eksonów, którego efektem prawdopodobnie jest śmierć patogena (Banno i wsp. 2009). Taka sytuacja ma miejsce m.in. u Alternaria solani, Pythium aphanidermatum, Pythium viticola, a także Pyrenophora teres (Broniarek-Niemiec i Bielenin 2005). Niewrażliwość izolatów $P$. teres na azoksystrobinę może wynikać ze wzrostu aktywności enzymu - alternatywnej oksydazy (AOX), który przekazuje elektrony z ubichinonu na tlen $\mathrm{W}$ procesie oddychania komórkowego $\mathrm{z}$ pominięciem cytochromu bc1 i oksydazy cytochromu $c$ (kompleks III i IV) (Broniarek-Niemiec 2016). Mechanizm taki określany jest jako alternatywne oddychanie. Występuje m.in. u Botrytis cinerea (Wood i Hollomon 2003), czy C. beticola (Pieczul i Perek 2015). Jednakże, ze względu na mniejszą ilość energii produkowanej w wyniku alternatywnego oddychania w stosunku do produkcji w szlaku $\mathrm{z}$ udziałem cytochromu $b$, jej skuteczność odgrywała znaczącą rolę dopiero w późniejszych fazach rozwojowych grzyba (Miguez i wsp. 2004).

\section{Wnioski / Conclusions}

1. Test wzrostu $P$. teres w obecności azoksystrobiny pozwolił na wstępne wykrycie form mniej wrażliwych na działanie fungicydów strobilurynowych. Spośród badanych izolatów $P$. teres aż 47,5\% wykazywała częściową lub całkowitą niewrażliwość na zastosowany fungicyd.

2. Wśród częściowo niewrażliwych na działanie azoksystrobiny izolatów P. teres nie wykryto mutacji F129L.

\section{Literatura / References}

Aamir S., Sutar S., Singh S.K., Baghela A. 2015. A rapid and efficient method of fungal genomic DNA extraction, suitable for PCR based molecular methods. Plant Pathology \& Quarantine 5 (2): 74-81. DOI: 10.5943/ppq/5/2/6.

Anke T. 1995. The antifungal strobilurins and their possible ecological role. Canadian Journal of Botany 73 (S1): $940-945$. DOI: 10.1139/b95-342.

Banno S., Yamashita K., Fukumori F., Okada K., Uekusa H., Takagaki M., Kimura M., Fujimura M. 2009. Characterization of QoI resistance in Botrytis cinerea and identification of two types of mitochondrial cytochrome b gene. Plant Pathology 58 (1): 120-129. DOI: 10.1111/j.1365-3059.2008.01909.x.

Baturo A. 2009. Effect of biopreparations on the health of grain of spring barley (Hordeum vulgare) in organic system. Phytopathologia 53: $19-30$.

Broniarek-Niemiec A. 2016. Odporność Venturia inaequalis na fungicydy ze szczególnym uwzględnieniem strobiluryn. [The resistance of Venturia inaequalis to fungicides, with the special emphasis of strobilurin]. Progress in Plant Protection 56 (1): 52-61. DOI: 10.14199/ppp-2016-009.

Broniarek-Niemiec A., Bielenin A. 2005. Monitoring odporności Venturia inaequalis na fungicydy strobilurynowe i dodynowe. [Monitoring of Venturia inaequalis resistance to strobiluryn and dodine fungicides]. Zeszyty Naukowe Instytutu Sadownictwa i Kwiaciarstwa 13: 143-150.

Deising H.B., Reimann S., Pascholati S.F. 2008. Mechanisms and significance of fungicide resistance. Brazilian Journal of Microbiology 39 (2): 286-295. DOI: 10.1590/S1517-838220080002000017. 
Doyle J.J., Doyle J.L. 1987. A rapid DNA isolation procedure for small quantities of fresh leaf tissue. Phytochemical Bulletin 19 (1): $11-15$.

Gąsiorowski H. 1997. Jęczmień - chemia i technologia. PWRiL, Poznań, 281 ss.

GUS 2016. Wyniki produkcji roślinnej w 2015 r. Główny Urząd Statystyczny, Warszawa, 92 ss.

Hani F., Popow G., Reinhard H., Schwarz A., Tanner K., Vorlet M. 1998. Ochrona roślin rolniczych w uprawie integrowanej. Choroby. Szkodniki. Organizmy pożyteczne. PWRiL, Warszawa, 332 ss.

Kryczyński S., Weber Z. (red.). 2011. Fitopatologia. Tom 2. Choroby roślin uprawnych. PWRiL, Poznań, 464 ss.

Leisova L., Kucera L., Minarikova V., Ovesna J. 2005. AFLP-based PCR markers that differentiate spot and net forms of Pyrenophora teres. Plant Pathology 54 (1): 66-73. DOI: 10.1111/j.1365-3059.2005.01117.x.

Marzani Q.A. 2011. Fungicide resistance and efficacy for control of Pyrenophora teres and Mycosphaerella graminicola on barley and wheat. University of Nottingham. Praca dyplomowa.

Miguez M., Reeve C., Wood P.M., Hollomon D.W. 2004. Alternative oxidase reduces the sensitivity of Mycosphaerella graminicola to QOI fungicides. Pest Management Science 60 (1): 3-7. DOI: 10.1002/ps.837.

Pieczul K. 2015. Przyczyny odporności na fungicydy grzybów patogenicznych dla roślin. Zagadnienia Doradztwa Rolniczego 1: 83-93.

Pieczul K., Perek A. 2015. Przyczyny odporności izolatów Cercospora beticola (chwościk buraka) na strobiluryny w Wielkopolsce. [The reasons of strobilurin resistance of Cercospora beticola (cercospora leaf spot) isolates in Wielkopolska region]. Progress in Plant Protection 55 (1): 45-48. DOI: 10.14199/ppp-2015-008.

Semar M., Strobel D., Koch A., Klappach K., Stammler G. 2007. Field efficacy of pyraclostrobin against populations of Pyrenophora teres containing the F129L mutation in the cytochrome b gene. Journal of Plant Diseases and Protection 114 (3): 117-119. DOI: 10.1007/BF03356718.

Sierotzki H., Frey R., Wullschleger J., Palermo S., Karlin S., Godwin J., Gisi U. 2007. Cytochrome b gene sequence and structure of Pyrenophora teres and P. tritici-repentis and implications for QoI resistance. Pest Management Science 63 (3): 225-233. DOI: 10.1002/ps.1330.

Wood P.M., Hollomon D.W. 2003. A critical evaluation of the role of alternative oxidase in performance of strobilurin and related fungicides acting at the Qo site of Complex III. Pest Management Science 59 (5): 499-511. DOI: 10.1002/ps.655.

Zalecenia ochrony roślin na lata 2016/2017. Cz. II. Rośliny rolnicze. 2016. Instytut Ochrony Roślin - Państwowy Instytut Badawczy, Poznań, 400 ss. 